\title{
CHRONIC MERCURY POISONING
}

\author{
BY \\ MONAMY BUCKELL, DONALD HUNTER, REGINALD MILTON \\ and KENNETH M. A. PERRY
}

\section{From the Department for Research in Industrial Medicine (Medical Research Council), The London Hospital}

The most prominent symptoms of chronic mercury poisoning are erethism, tremor and stomatitis. The psychic disturbance known as erethism is the first of the symptoms to develop; it is a peculiar form of timidity most evident in the presence of strangers. The name is derived from the Greek word ' red' and is attributed to the blushing embarrassment of the sufferer. John Pearson of London (1758--1826) first gave the symptom complex the name erethism (Almkvist, 1929). The man affected is easily upset and embarrassed, loses all joy in life and lives in constant fear of being dismissed from his job. He has a sense of timidity and may lose self control before visitors. Thus, if one stops to watch such a man in a factory, he will sometimes throw down his tools and turn in anger on the intruder, saying he cannot work if watched. Occasionally a man is obliged to give up work because he can no longer take orders without losing his temper or, if he is a foreman, because he has no patience with men under him. Drowsiness, depression, loss of memory and insomnia may occur, but hallucinations, delusions and mania are rare

The most characteristic symptom, though it is seldom the first to appear, is mercurial tremor. It is neither as fine nor as regular as that of hyperthyroidism. It may be interrupted every few minutes by coarse jerky movements. It usually begins in the fingers, but the eyelids, lips and tongue are affected early. As it progresses it passes to the arms and legs, so that it becomes very difficult for a man to walk about the workshop, and he may have to be guided to his bench. At this stage the condition is so obvious that it is known to the layman as ' hatter's shakes.' The tremor often passes away if the patient gives up his work before it has reached a serious stage; if this is delayed the tremor may persist for 15 or 20 years. Alcoholism favours its development, and it is claimed that no total abstainer has ever suffered from tremor in severe form.

Stomatitis manifests itself by salivation and tenderness of the gums. The gums are swollen and bleed readily and, rarely, a mercurial line is seen on the gums; it usually resembles the blue line of lead poisoning, though sometimes it is dark brown. Neal and his colleagues (1941) report that dermographia, excessive perspiration, pallor and an abnormal readiness to blush are manifestations of chronic mercurialism, while Adler (1891), Jacobsohn (1920) and Tylecote (1912) have reported increased deep tendon reflexes as part of the clinical picture.

These symptoms of chronic mercury poisoning must be clearly differentiated from those of acute mercurial poisoning, which rarely arises in industry and usually results from the use of drugs such as mercury bichloride, taken in excess, either by accident or with suicidal intent. Diarrhoea is usually the first symptom: the stools, faeculent at first, soon become watery, profuse and bloodstained. They often contain pieces of mucous membrane and have a disagreeable odour. Marked tenesmus and severe pain in the lower abdomen are usually present. In some cases vomiting occurs even when the poison has not been taken by mouth. Renal symptoms are also common; there is a marked reduction in the output of urine, which may lead to complete anuria. The urine containso red and white blood cells as well as alburnin and epithelial and granular casts. Headache andō somnolence follow and death from uraemia usually? occurs within several days.

As to poisoning by organic mercury compounds, Evans and Perry (1943) reported immediate death following the intravenous administration of mercurial diuretics in six patients, and many more cases have been reported in the United States. Hunter, Bomford and Russell (1940) drew attention to the extremely different nature of poisoning with methyl mercury compounds. Salivation, stomatitis and erethism were absent, and the nervous system alone is involved. The symptoms were severe generalized ataxia, dysarthria, and gross constriction of the visual fields, while memory and intelligence were unaffected. There was an intense and widespread degeneration of certain sensory paths of the nervous system, the peripheral nerves and posterior spinal roots being affected first; the posterior columns and the granular layer of the middle lobe of the cerebellum later.

Mercury fulminate is handled in explosives factories where detonators and percussion caps are made. The substance readily gives rise to dermatitis. Generally the uncovered parts of the body are attacked by an erythema, accompanied by intense 
itching, swelling and oedema, particularly on the face, eyelids, neck, behind the ears and on the forearms. Erythematous papules break out on the inflamed areas and may become vesicles, bullae and pustules. A pustular folliculitis often develops on the hairy parts of the skin. A grain of fulminate may lodge in a crack or abrasion of the skin and act as a corrosive, causing small painful necrotic lesions, especially in the tips of the fingers (' powder holes ') which last about fourteen days (Macleod, 1916). If fulminate attacks the knuckles or roots of the nails, ulceration may penetrate to the joint and bone. Exceptionally, the whole body is affected. Recovery takes place in one or two weeks, and is accompanied by desquamation.

\section{History of Industrial Mercurialism}

Quicksilver has been mined in Spain since Roman times, and we know that mercurialism was recognized even then, for Pliny mentions it in writing of the diseases of slaves. Gabrule Fallopius (15231562) in his treatise 'De metallis et fossilibus' noted that the workers in quicksilver mines suffered from mercury poisoning, and that the majority of miners remain at this work for barely three years (Rosen, 1943). Andre Mattioli of Siena, a contemporary of Fallopius, observed chronic mercurialism among the miners of quicksilver at Idria, in Carncola. Pister van Foreest (1522-1597) of Delft, also made similar observations. In 1665 tremors affecting the hands of workers in cinnabar mines in Italy led to the shortening of the working day to six hours; this is said to be the first legislative measure of industrial hygiene known to history (Hamilton, 1922). Several interesting observations relating to occupational mercurialism among miners were made during the eighteenth century. In 1719 Bernard de Lussein presented a memoir to the Academy of Sciences in which he reported the condition of the workers in the Almaden mercury mines in Spain. Both free and slave labour were employed there, and both groups of workers suffered from mercury poisoning. Nevertheless, the free miners kept themselves clean, and the only evidence of mercurialism which was exhibited was slight tremor. The slaves, on the other hand, imprisoned in their unclean quarters, and without any adequate means of washing, were afflicted with swellings of the parotid glands, stomatitis, salivation and pustular rashes. Giovanni Scopoli described mercury poisoning with the characteristic trembling among miners around Alto Isonzo. In 1804 there was a fire in a quicksilver mine in Austria and mercury vapour escaped into the air and spread over the countryside; 900 persons in the neighbourhood had mercurial tremor and many cows suffered from salivation, cachexia and abortion. In 1810 a British ship had some mercury containers broken in the hold, as a result of which all the birds and cattle on board died, and 200 persons in the ship developed symptoms of mercury poisoning, and three of them died. In 1861 Kussmaul painted a vivid picture of industrial.mercurialism amongst the mirror makers of Nuremberg in the days when the method of backing mirrors with quicksilver was still used. Chronic mercurialism in the felt hat industry was first described in St. Petersburg in 1829 (Hamilton, 1922) and later reported in New Jersey by Freeman in 1860 and Dennis (1878) and in England accounts were given from Guy's Hospital in 1864 by A. G. Taylor, and in 1901 by J. G. Taylor. Reports of mercury poisoning occurring in laboratory workers using physical apparatus have recently been published (Christensen, Krogh, and Nielsen 1937; McCarroll, 1939).

\section{Industries with a Risk of Mercurialism}

Occupations giving rise to the risks of exposure to metallic mercury and its inorganic salts include mercury mining, recovery of the metal from ore, separation of gold and silver from their ores by means of an amalgam with mercury, manufacture of some types of electric meters, electric lamps and radio valves, water gilding in which an amalgam of gold or silver is applied to the object concerned and the mercury volatilized by heat, manufacture of surgical dressings containing mercury salts, bronzing of field glasses and photo-engraving, the felting of fur and the manufacture of hard felt hats, the manufacture of tungsten-molybdenum rod and wire (Lewis, 1945), the manufacture of barometers and thermometers, and in the chemical industry, particularly in the preparation of pharmaceutical compounds of mercury. According to Bloomfield and his colleagues there were 32,855 persons exposed to a mercury hazard in the United States in 1940, the principal danger being in the felt hat industry. It is from this that the phrase ' as mad as a hatter' is derived. The fine hairs which form the fur of rabbits, hares, muskrats, and beavers are smooth, resilient and straight. Treatment with some chemical substance, and, until recently, an acid solution of mercuric nitrate, was mostly used to make them limp, twisted and rough, thus greatly aiding the felting process. Matting felt means matting fine hairs together, shrinking and pressing them till the mat is firm and hard.

Neal and his colleagues (1941) examined 534 hatters employed in five representative felt hat factories and showed that 59 had signs of chronic mercurialism. Four of the twenty-one men engaged in mixing and blowing, eight of the 34 coners, 6 of the 29 hardeners, and 33 of the 179 starters, wetters down, and sizers were so diagnosed. Mixers and blowers were exposed to $5 \mu \mathrm{g}$. of mercury per $10 \mathrm{cu} . \mathrm{m}$. of air, hardeners to $2 \cdot 7$, and starters, wetters down, and size1s to $2.1 \mu \mathrm{g}$. In any range of exposure above $100 \mu \mathrm{g}$. mercury per cu. $\mathrm{m}$. the incidence of mercurialism increased with increasing duration of employment. No cases were found among hatters exposed to less than $100 \mu \mathrm{g}$. per cu. $\mathrm{m}$. as measured by the Nordlander instrument. Workers with raised systolic blood pressure and albuminuria tended to excrete less mercury in their urine than similarly exposed workers who were normal in these respects. Patients with mercurialism were found to excrete 
slightly less mercury in their urine than similarly exposed but non-affected workers. Substantial percentages of urine samples from workers with the heaviest mercury exposure were found to be free from mercury; but this finding was not confirmed in investigations subsequently carried out by Storlazzi and Elkins (1941).

Alice Hamilton (1943) stresses the fact that the Spanish quicksilver mines are dangerous because they contain pure mercury; whereas in California, Nevada, Texas and Oregon they mostly contain red cinnabar-mercury sulphide. However, in some in Sonoma County the quicksilver runs free; these are so dangerous that men became poisoned within two weeks and they have had to close down. From cinnabar a temperature of $400^{\circ}$. C. releases the metal. It is therefore dangerous for workers to handle tobacco in such work, as the heat freely volatilizes the mercury. The men are careful not to take clothes home with them.

Mercury poisoning in industry has never been fully investigated. The factors responsible are first the difficulty of being sure that the early symptoms are caused by mercury, and secondly that of finding a method capable of identifying, differentiating and estimating mercury in micro amounts. It is impossible to distinguish early erethism from shyness or anxiety neurosis; similarly it is difficult to distinguish early mercurial tremor from that of hyperthyroidism or anxiety neurosis, especially when all the workers already know that tremor is the cardinal sign of mercury poisoning. Difficulties arise in differentiating mercurial stomatitis from pyorrhoea, which is so common in the general population, and from Vincent's stomatitis, outbreaks of which have been not uncommon in the general population during the last five years. McGeorge (1935) discussed the difficulty of this diagnosis and suggested microscopical examination of the floor of the mouth would help to differentiate, and that in chronic mercurial stomatitis there was a characteristic odour. This was not observed in the series of patients to be described.

The most intensive work on the chemical side has been carried out by Stock $(1931,1943)$ in Berlin, who devised a method for the estimation of traces of mercury in the air and of biological materials. It consists of bringing the mercury into solution in the form of mercuric chloride, separating the metal electrolytically on a copper wire, distilling the mercury from the wire to form metallic droplets, which are then measured with the aid of a special microscope. He claimed to be able to detect quantities of mercury as low as $0.001 \mu \mathrm{g}$., but obviously such a method would demand considerable experience if it is to give reliable results. He claimed that mercury was present in a wide variety of materials and that the normal human intake in foodstuffs amounted to $0 \cdot 1-1 \mu \mathrm{g}$. per day, and that about the same amount is excreted mainly in the urine, while the normal content of the blood is about $0.1 \mu \mathrm{g}$. per $100 \mathrm{~g}$. Teeth with amalgam fillings increased the urinary excretion from 20 to
$30 \mu \mathrm{g}$. daily. Mercury accumulated mainly in the kidneys, but also to a minor extent in the hair, finger-nails and muscles. There is a considerable accumulation in the endocrine glands, particularly the pituitary body, and Stock considered that this explained the nervous symptoms of chronic mercury poisoning. Chemists, dentists and industrial workers, he claimed, were prone to mild chronic mercurialism, and excreted several micrograms of the metal in their urine, while the blood mercury rapidly increased after exposure. Much work was carried out on laboratory workers, and the presence of globules of mercury in floors or behind benches was sufficient to raise the air concentration to levels likely to cause chronic mercurialism. Stock stated that much larger quantities of mercury could be taken by mouth than when breathed, before symptoms became manifest.

\section{Present Investigation}

In an attempt, therefore, to throw light on the problem of mercury poisoning, investigations have been carried out in one factory manufacturing physical apparatus, and in another where pharmaceutical compounds of mercury were being prepared. The principal physical apparatus involving the use of mercury is the thermometer. Clinical thermometers are made from strips of glass tubing which are cut to the required length. Each of these lengths is opened out to form the blister by means of a gas flame and air pump; the bulb is then blown. The next process is that of filling the bulb by inverting the tubes in a bowl of mercury, and the tubes are then boiled to remove any pocket of air. The thermometers are then tested by standard comparisons. The tops of the stems are next sealed, the blister is contracted, the heads are rounded off, and the thermometer engraved. During the process the workmen are exposed to the vapour of mercury, hot and bright flickering flames, hydrofluoric acid fumes, coal gas from leaking pipes and glass dust. Mercury can always be found in cracks and crevices on work benches and floors.

\section{Clinical Observations}

Some 72 men were examined in the workshop where thermometers were being made, and 11 men in the chemical works making mercurial compounds. Slight degrees of erethism and tremor must always be a matter of opinion, and in the tables which follow the opinion of one of us (K. P.) is recorded. An attempt was made to record the tremor by asking each man to write his name and address on a piece of paper, and to draw two straight lines, both in a horizontal and vertical direction. Fig. 1 shows an example of the results which were obtained. Gingivitis and salivation are common in the working population and there was no proof that any given case was attributable to mercury. The mass observation in these works suggests that most of the workers were suffering from mild degrees of mercury poisoning, but in no individual were the symptoms so severe that they could be attributed 
without doubt to mercury, nor were they such as to produce any disability in the men, or any inability to work: but it is undesirable that any section of the population should be mildly intoxicated by any substance, and as a result of this work it is hoped that it may be possible to prevent this.

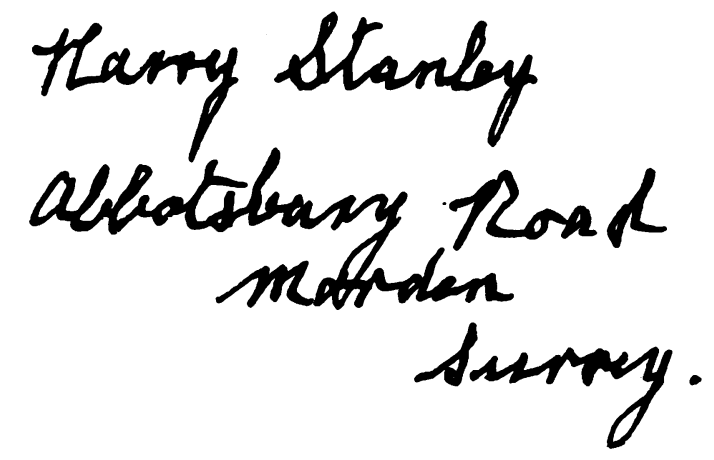

FIG. 1.-Specimen of handwriting and free-hand drawing of thermometer maker with mercurial tremor.

Groups of workers from each section of the factory were examined, and blood counts were taken. These revealed no abnormality, so that there is no confirmation of the reports by Dunajewsky and Peissakhovitch (1930) and Matussevic and Frumina (1936) that a lymphocytosis is a distinctive blood finding. Specimens of urine were collected over a 24-hours period at the week-end while the workers were clear of contamination in the factory (Tables 1, 2, 3, 4 and 5) and compared with specimens from 15 male controls taken from another factory where there was no contact with mercury (Table 6). These were examined quantitatively for mercury by the method of Milton (1946) the outline of which is as follows :

Principle. Organic matter was removed by oxidation and the mercury precipitated as sulphide using arsenic as co-precipitant. The mixed sulphides were separated from the solution and dissolved and the colour given by the mercury with a chloroform solution of dithizone was compared with that given by a standard mercury solution.

Reagents. Distilled water from all glass still.

Potassium permanganate.

Oxalic acid.

1 per cent. aqueous solution of sodium arsenite.

Hydrogen sulphide.

Concentrated nitric acid.

Concentrated hydrochloric acid.

Hydroxylamine hydrochloride.

10 per cent. ammonia.
Chloroform.

Dithizone (diphenylthiocarbazone).

Anhydrous sodium sulphate.

Sodium hypobromite solution.

Concentrated sulphuric acid.

Preparation of Dithizone Solution. It was found necessary to redistill all chloroform and ammonia before use; even the pure reagents contained traces of heavy metals.

Ten milligrammes of dithizone was dissolved in $50 \mathrm{ml}$. of redistilled chloroform and the solution shaken with $50 \mathrm{ml}$. of 10 per cent. ammonia. The chloroform layer was allowed to settle and drawn off. This separated most of the dithizone into the ammoniacal layer, leaving the impurities in the chloroform layer. Hydrochloric acid was added drop by drop to the aqueous solution until it was acid and no further precipitation of dithizone took place. The precipitate was dissolved in $100 \mathrm{ml}$. of chloroform and the chloroform drawn off; $20 \mathrm{ml}$. of this stock solution was diluted to $100 \mathrm{ml}$. with chloroform before use.

Calibration Graph. Using the Spekker Photoelectric Absorbtiometer a calibration graph was constructed from 0 to $50 \mu \mathrm{g}$. mercury. This calibration was repeated every time a fresh lot of any reagent came into use.

Blank. Fifteen $\mathrm{ml}$. of the diluted dithizone solution was shaken with about $20 \mathrm{ml}$. of 10 per cent. ammonia and separated, and the process repeated with another $20 \mathrm{ml}$. of ammonia. The chloroform solution was dried by the addition of a little anhydrous sodium sulphate, and the colour read on the Spekker using the blue Mo.6 screen. In cases where the blank reading was more than.10 a fresh dithizone solution was prepared and the blank repeated.

Mercury Standards. A standard solution of mercuric nitrate, containing $50 \mathrm{mg}$. per cent. of mercury was made up. This was diluted 1 in 100 and from this standards containing, in $100 \mathrm{ml}$. of solution, from 5 to $50 \mu \mathrm{g}$. of mercury in $5 \mu \mathrm{g}$. steps were prepared. To each standard, in a separating funnel, $1 \mathrm{ml}$. of concentrated hydrochloric acid was added, then $3 \mathrm{ml}$. of dithizone solution and the funnel well shaken and allowed to stand. The chloroform layer was withdrawn into a 50-ml. graduated, stoppered cylinder. The extraction was repeated with four further 3-ml. portions of dithizone, making $15 \mathrm{ml}$. in all. The $15 \mathrm{ml}$. of dithizone extract was shaken with two 20 -ml. portions of 10 per cent. ammonia to remove excess reagent, and dried with anhydrous sodium sulphate as in the case of the blank. The orange mercury-dithizone colour produced was read in the Spekker, and a graph constructed of Spekker reading minus blank against mercury concentration.

The method was developed for urine but could be adapted for use with blood or other tissues.

A 24-hour specimen of urine was collected and the volume recorded. Five hundred $\mathrm{ml}$. of urine was refluxed with $20 \mathrm{ml}$. of concentrated sulphuric acid and $\mathbf{1 0}$ grams of potassium permanganate for three hours. While still warm 10 grams of oxalic 
TABLE 1

CALIBRATING AND POINTING

\begin{tabular}{|c|c|c|c|c|c|c|c|c|c|c|c|c|c|c|c|}
\hline \multirow{2}{*}{$\begin{array}{c}\text { Case. } \\
\text { No }\end{array}$} & \multirow{2}{*}{ Age } & \multirow{2}{*}{$\begin{array}{c}\text { Duration } \\
\text { of employ- } \\
\text { ment. } \\
\text { Years }\end{array}$} & \multirow{2}{*}{ Erethism } & \multirow{2}{*}{ Tremor } & \multirow{2}{*}{$\begin{array}{c}\text { Stoma- } \\
\text { titis }\end{array}$} & \multicolumn{3}{|c|}{ Urine } & \multicolumn{7}{|c|}{ Blood count } \\
\hline & & & & & & $\begin{array}{c}\text { Volume } \\
\text { in } 24 \mathrm{hrs} . \\
\mathrm{ml} .\end{array}$ & $24 \mathrm{hrs}$. & p.p.m. & $\mathrm{Hb}$. & $\mathbf{R}$ & W & $\mathbf{P}$ & $\mathbf{L}$ & $\mathbf{M}$ & E \\
\hline $\begin{array}{l}1 \\
2 \\
3 \\
4 \\
5 \\
6 \\
7\end{array}$ & $\begin{array}{l}17 \\
17 \\
28 \\
18 \\
29 \\
29 \\
25\end{array}$ & $\begin{array}{r}2 \\
3 \\
15 \\
4 \\
15 \\
15 \\
11\end{array}$ & $\begin{array}{l}- \\
\overline{+} \\
+ \\
- \\
- \\
-\end{array}$ & $\begin{array}{l}- \\
\overline{+} \\
+ \\
+ \\
+ \\
+\end{array}$ & $\begin{array}{l}- \\
- \\
- \\
\overline{+} \\
+\end{array}$ & $\begin{array}{l}\overline{-} \\
2200 \\
\overline{1040} \\
1600 \\
-\end{array}$ & $\begin{array}{l}\overline{\overline{175}} \\
\overline{278} \\
136 \\
-\end{array}$ & $\begin{array}{c}\bar{Z} \\
0.080 \\
0 . \overline{267} \\
0.085 \\
-\end{array}$ & $\begin{array}{l}116 \\
119 \\
107 \\
119 \\
114 \\
118 \\
114\end{array}$ & $\begin{array}{l}6 \cdot 0 \\
6 \cdot 3 \\
5 \cdot 0 \\
6 \cdot 0 \\
5 \cdot 6 \\
6 \cdot 0 \\
5 \cdot 4\end{array}$ & $\begin{array}{r}7.8 \\
11.8 \\
6.8 \\
15.6 \\
12.8 \\
16.8 \\
6.0\end{array}$ & $\begin{array}{l}65 \\
70 \\
66 \\
78 \\
62 \\
56 \\
64\end{array}$ & $\begin{array}{l}28 \\
25 \\
32 \\
21 \\
33 \\
37 \\
24\end{array}$ & $\begin{array}{l}5 \\
5 \\
2 \\
1 \\
4 \\
7 \\
3\end{array}$ & $\frac{1}{-}$ \\
\hline
\end{tabular}

TABLE 2

CONTRACTORS

\begin{tabular}{|c|c|c|c|c|c|c|c|c|c|c|c|c|c|c|c|}
\hline \multirow{2}{*}{$\begin{array}{c}\text { Case } \\
\text { No. }\end{array}$} & \multirow[b]{2}{*}{ Age } & \multirow{2}{*}{$\begin{array}{c}\text { Duration } \\
\text { of employ- } \\
\text { ment. } \\
\text { Years }\end{array}$} & \multirow{2}{*}{ Erethism } & \multirow{2}{*}{ Tremor } & \multirow{2}{*}{$\begin{array}{l}\text { Stoma- } \\
\text { titis }\end{array}$} & \multicolumn{3}{|c|}{ Urine } & \multicolumn{7}{|c|}{ Blood count } \\
\hline & & & & & & $\begin{array}{c}\text { Volume } \\
\text { in } 24 \mathrm{hrs} . \\
\mathrm{ml} .\end{array}$ & $\cdot 24 \mathrm{hrs}$ & p.p.m. & $\mathrm{Hb}$. & $\mathbf{R}$ & W & $\mathbf{P}$ & L & $\mathbf{M}$ & E \\
\hline 8 & 17 & 3 & + & + & - & 2350 & 2260 & 0.961 & 121 & $6 \cdot 0$ & $7 \cdot 6$ & 58 & 36 & 4 & 2 \\
\hline 9 & 39 & 25 & - & ++ & + & 130 & 500 & & 116 & $5 \cdot 4$ & $15 \cdot 2$ & 68 & 30 & 1 & 1 \\
\hline 10 & 16 & 2 & - & + & - & 2300 & 3478 & $1 \cdot 5$ & 108 & $5 \cdot 4$ & 13.0 & 66 & 32 & 2 & 二 \\
\hline 11 & 17 & 2 & - & + & - & 1500 & 866 & 0.5 & 112 & $5 \cdot 7$ & 12 & 64 & 32 & 3 & 1 \\
\hline 12 & 18 & $\overline{3}$ & - & + & + & 1500 & 650 & 0.433 & 111 & 5 & 10.0 & 65 & 30 & 5 & 一 \\
\hline 13 & 23 & 6 & + & ++ & + & - & - & - & 11 & 5 & $8 \cdot 4$ & 60 & 30 & 5 & - \\
\hline 14 & 30 & 16 & + & ++ & - & - & - & - & 10 & 5 & 9 & 8 & 30 & 2 & - \\
\hline 15 & 29 & 15 & - & + & + & - & - & - & 11 & 5 & 7 & 58 & 30 & 10 & 2 \\
\hline 16 & 39 & 5 & - & + & + & - & - & - & 10 & & 6 & & & 5 & 4 \\
\hline 17 & 31 & 12 & - & + & - & - & - & - & 11 & 5 & $16 \cdot 0$ & 50 & 45 & 4 & 1 \\
\hline 18 & 30 & 16 & - & ++ & + & - & - & - & 11 & 5. & & 67 & 24 & 9 & 一 \\
\hline 19 & & 16 & 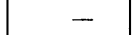 & r & . & 1600 & 900 & 0.56 & 10 & 5 & 17 & & 34 & 3 & - \\
\hline 20 & 28 & 14 & - & + & + & 2000 & 900 & 0.450 & 11 & 5 . & 11.9 & 57 & 39 & 3 & 1 \\
\hline 21 & 39 & 19 & ++ & + & - & - & - & - & 10 & 5 & 8 & 62 & 34 & 2 & 1 \\
\hline & 31 & 12 & & ++ & + & - & - & - & 10 & 5. & 9 & 63 & 31 & 4 & 1 \\
\hline 23 & 31 & 17 & - & + & + & 1800 & 540 & 0.300 & 10 & 5 & 9 & & 36 & 5 & \\
\hline 24 & 3 & 6 & - & + & + & 1700 & 340 & 0.20 & 11 & 5 & 15 & 64 & 52 & 4 & 1 \\
\hline 25 & 30 & 16 & - & + & - & 250 & 300 & 0.12 & 11 & 5. & 16 & 0 & 26 & 3 & 1 \\
\hline 26 & 40 & 26 & + & + & + & 2300 & 380 & $0 \cdot 165$ & 114 & $5 \cdot 7$ & $8 \cdot 0$ & 60 & 33 & 4 & 3 \\
\hline
\end{tabular}

TABLE 3

HEAT TREATMENT AND BOILING IN

\begin{tabular}{|c|c|c|c|c|c|c|c|c|c|c|c|c|c|c|c|}
\hline \multirow{2}{*}{$\begin{array}{c}\text { Case } \\
\text { No. }\end{array}$} & \multirow{2}{*}{ Age } & \multirow{2}{*}{$\begin{array}{c}\text { Duration } \\
\text { of employ } \\
\text { ment. } \\
\text { Years }\end{array}$} & \multirow{2}{*}{ Erethism } & \multirow{2}{*}{ Tremor } & \multirow{2}{*}{$\begin{array}{c}\text { Storna- } \\
\text { titis }\end{array}$} & \multicolumn{3}{|c|}{ Urine } & \multicolumn{7}{|c|}{ Blood Counts } \\
\hline & & & & & & $\begin{array}{l}\text { Volume } \\
\text { in } 24 \mathrm{hrs} . \\
\mathrm{ml} .\end{array}$ & $24 \mathrm{~g}$ & o.p.m. & $\mathrm{Hb}$. & $\mathbf{R}$ & W & $\mathbf{P}$ & L & $\mathbf{M}$ & E \\
\hline $\begin{array}{l}27 \\
28 \\
29 \\
30 \\
31 \\
.32\end{array}$ & $\begin{array}{l}41 \\
56 \\
18 \\
22 \\
27 \\
48\end{array}$ & $\begin{array}{r}12 \\
1 \\
4 \\
8 \\
15 \\
14\end{array}$ & $\begin{array}{r}++ \\
+ \\
+ \\
+ \\
+ \\
+\end{array}$ & $\begin{array}{r}++ \\
+ \\
+ \\
+ \\
+ \\
++\end{array}$ & $\begin{array}{l}- \\
- \\
\overline{-} \\
\pm\end{array}$ & $\begin{array}{r}2240 \\
1400 \\
880 \\
1550 \\
1230 \\
1500\end{array}$ & $\begin{array}{l}2280 \\
1200 \\
2050 \\
1420 \\
1250 \\
1160\end{array}$ & $\begin{array}{l}1.017 \\
0.857 \\
2.329 \\
0.916 \\
1.015 \\
0.773\end{array}$ & $\begin{array}{r}108 \\
97 \\
110 \\
124 \\
111 \\
114\end{array}$ & $\begin{array}{l}5 \cdot 4 \\
5 \cdot 8 \\
5 \cdot 5 \\
6 \cdot 0 \\
5 \cdot 6 \\
5 \cdot 6\end{array}$ & $\begin{array}{l}15.6 \\
11.8 \\
10 \cdot 0 \\
11 \cdot 2 \\
10 \cdot 8 \\
10 \cdot 0\end{array}$ & $\begin{array}{l}59 \\
56 \\
60 \\
66 \\
60 \\
67\end{array}$ & $\begin{array}{l}36 \\
37 \\
32 \\
27 \\
34 \\
27\end{array}$ & $\begin{array}{l}5 \\
5 \\
5 \\
6 \\
5 \\
4\end{array}$ & $\begin{array}{l}1 \\
1 \\
2 \\
1 \\
1 \\
2\end{array}$ \\
\hline
\end{tabular}

Haemoglobin by photo-electric alkaline haematin method 100 per cent. equivalent 13.8 grams per $100 \mathrm{ml}$. 
TABLE 4

BLOWING AND FINISHING

\begin{tabular}{|c|c|c|c|c|c|c|c|c|c|c|c|c|c|c|c|}
\hline \multirow{2}{*}{$\begin{array}{c}\text { Case } \\
\text { No. }\end{array}$} & \multirow{2}{*}{ Age } & \multirow{2}{*}{$\begin{array}{l}\text { Duration } \\
\text { of employ } \\
\text { ment. } \\
\text { years }\end{array}$} & \multirow{2}{*}{ Erethism } & \multirow[b]{2}{*}{ Tremor } & \multirow{2}{*}{$\begin{array}{c}\text { Stoma- } \\
\text { titis }\end{array}$} & \multicolumn{3}{|c|}{ Urine } & \multicolumn{7}{|c|}{ Blood count } \\
\hline & & & & & & $\begin{array}{c}\text { Volume } \\
\text { in } 24 \mathrm{hrs} . \\
\mathrm{ml} .\end{array}$ & $24 \mathrm{hrs}$. & p.p.m. & Hb. & $\mathbf{R}$ & $\mathbf{W}$ & $\mathbf{P}$ & $\mathbf{L}$ & $\mathbf{M}$ & $\mathbf{E}$ \\
\hline $\begin{array}{l}33 \\
34 \\
35 \\
36 \\
37 \\
38 \\
39 \\
40 \\
41 \\
42 \\
43 \\
44 \\
45 \\
46 \\
47 \\
48 \\
49 \\
50 \\
51 \\
52 \\
53 \\
54 \\
55 \\
56 \\
57 \\
58 \\
59 \\
60 \\
61 \\
62 \\
63 \\
64 \\
65\end{array}$ & $\begin{array}{l}31 \\
25 \\
27 \\
44 \\
38 \\
32 \\
25 \\
22 \\
24 \\
17 \\
22 \\
31 \\
39 \\
44 \\
29 \\
28 \\
28 \\
32 \\
16 \\
22 \\
16 \\
25 \\
25 \\
18 \\
18 \\
15 \\
15 \\
16 \\
16 \\
16 \\
18 \\
42 \\
49\end{array}$ & $\begin{array}{r}15 \\
10 \\
13 \\
12 \\
17 \\
18 \\
11 \\
9 \\
10 \\
3 \\
7 \\
17 \\
17 \\
30 \\
15 \\
13 \\
14 \\
15 \\
2 \\
5 \\
1 \\
10 \\
10 \\
3 \\
2 \\
1 \\
1 \\
2 \\
1 \\
2 \\
2 \\
28 \\
6\end{array}$ & $\begin{array}{r} \pm \\
\overline{-} \\
\pm \\
= \\
= \\
\pm \\
\pm \\
= \\
\pm \\
\pm \\
\pm \\
\pm \\
++ \\
\pm \\
\pm \\
= \\
\pm \\
\pm \\
\pm \\
+ \\
\pm \\
\pm \\
\pm \\
\pm \\
\pm\end{array}$ & $\begin{array}{r}+ \\
+ \\
+ \\
+ \\
+ \\
+ \\
+ \\
+ \\
++ \\
\pm \\
+ \\
+ \\
+ \\
+ \\
+ \\
+ \\
+ \\
+ \\
\pm \\
+ \\
+ \\
\pm \\
+ \\
\pm \\
\pm \\
\pm \\
\pm \\
\pm \\
\pm \\
=\end{array}$ & $\begin{array}{l}- \\
= \\
= \\
+ \\
\pm \\
= \\
= \\
= \\
= \\
+ \\
+ \\
\pm \\
\pm \\
\pm \\
= \\
- \\
- \\
= \\
= \\
= \\
= \\
= \\
= \\
= \\
= \\
= \\
=\end{array}$ & $\begin{array}{r}1300 \\
1160 \\
900 \\
1200 \\
2250 \\
2400 \\
1520 \\
710 \\
1240 \\
2050 \\
1300 \\
2290 \\
1200 \\
1760 \\
1100 \\
1940 \\
2460 \\
= \\
\overline{-} \\
1220 \\
910 \\
1110 \\
2600 \\
1190 \\
1700 \\
1 \overline{1715} \\
\overline{-} \\
\overline{1850} \\
1190\end{array}$ & $\begin{array}{r}730 \\
1700 \\
800 \\
1440 \\
1350 \\
1200 \\
885 \\
280 \\
2261 \\
\overline{1435} \\
695 \\
1250 \\
540 \\
235 \\
643 \\
545 \\
2360 \\
- \\
\overline{-} \\
528 \\
213 \\
1775 \\
1680 \\
1145 \\
276 \\
\overline{885} \\
\overline{1} \\
\overline{142} \\
2110\end{array}$ & $\begin{array}{l}0.561 \\
1.465 \\
0.976 \\
1.200 \\
0.600 \\
0.500 \\
0.582 \\
0.394 \\
1.823 \\
\overline{0}-700 \\
0.535 \\
0.546 \\
0.450 \\
0.133 \\
0.585 \\
0.282 \\
0.959 \\
- \\
\overline{-} \\
0.432 \\
0.234 \\
1.630 \\
0.646 \\
0.962 \\
0.162 \\
\overline{0} \\
0.518 \\
- \\
0.077 \\
1.771\end{array}$ & $\begin{array}{l}116 \\
116 \\
119 \\
107 \\
101 \\
124 \\
125 \\
127 \\
120 \\
116 \\
111 \\
125 \\
111 \\
116 \\
100 \\
118 \\
123 \\
119 \\
117 \\
120 \\
110 \\
119 \\
116 \\
112 \\
114 \\
108 \\
111 \\
103 \\
108 \\
110 \\
103 \\
119 \\
105\end{array}$ & $\begin{array}{l}6.0 \\
5.6 \\
5.8 \\
5.4 \\
5.2 \\
5.8 \\
6.0 \\
6.0 \\
5.9 \\
5 \cdot 4 \\
5.4 \\
6.2 \\
4.9 \\
5.9 \\
4.8 \\
6.4 \\
6.0 \\
5.6 \\
6.0 \\
6.0 \\
5.5 \\
6.1 \\
5.8 \\
5.4 \\
5.6 \\
5.5 \\
5.6 \\
5.2 \\
5.6 \\
5.0 \\
5.4 \\
5.5 \\
5.6\end{array}$ & 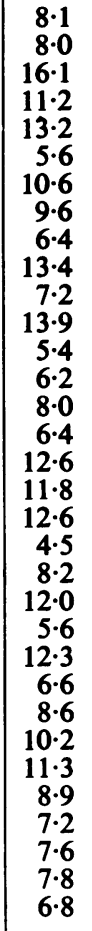 & $\begin{array}{l}70 \\
67 \\
66 \\
62 \\
60 \\
56 \\
64 \\
60 \\
64 \\
59 \\
67 \\
54 \\
58 \\
69 \\
66 \\
67 \\
64 \\
59 \\
69 \\
58 \\
64 \\
66 \\
54 \\
66 \\
59 \\
57 \\
54 \\
61 \\
60 \\
65 \\
71 \\
64\end{array}$ & $\begin{array}{l}26 \\
30 \\
32 \\
29 \\
34 \\
39 \\
32 \\
34 \\
32 \\
34 \\
29 \\
43 \\
36 \\
25 \\
31 \\
29 \\
33 \\
35 \\
25 \\
38 \\
32 \\
30 \\
39 \\
30 \\
36 \\
36 \\
40 \\
33 \\
34 \\
30 \\
22 \\
29\end{array}$ & $\begin{array}{l}4 \\
3 \\
2 \\
6 \\
3 \\
4 \\
2 \\
4 \\
4 \\
7 \\
3 \\
2 \\
5 \\
4 \\
3 \\
3 \\
1 \\
5 \\
6 \\
3 \\
3 \\
4 \\
4 \\
3 \\
4 \\
5 \\
4 \\
5 \\
6 \\
4 \\
4 \\
4\end{array}$ & $\begin{array}{c}\text { 二 } \\
\overline{-} 2 \\
3 \\
1 \\
2 \\
1 \\
-\overline{1} \\
1 \\
1 \\
1 \\
1 \\
1 \\
1 \\
1 \\
1 \\
1 \\
1 \\
3 \\
2 \\
1 \\
1 \\
2 \\
2 \\
\\
\\
1 \\
3 \\
2\end{array}$ \\
\hline
\end{tabular}

TABLE 5

GLASS BLOWING AND BENDING

\begin{tabular}{|c|c|c|c|c|c|c|c|c|c|c|c|c|c|c|c|}
\hline \multirow{2}{*}{$\begin{array}{l}\text { Case } \\
\text { No. }\end{array}$} & \multirow[b]{2}{*}{ Age } & \multirow{2}{*}{$\begin{array}{c}\text { Duration } \\
\text { of employ- } \\
\text { ment. } \\
\text { Years }\end{array}$} & \multirow{2}{*}{ Erethism } & \multirow[b]{2}{*}{ Tremor } & \multirow[b]{2}{*}{$\begin{array}{l}\text { Stoma- } \\
\text { titis }\end{array}$} & \multicolumn{3}{|c|}{ Urine } & \multicolumn{7}{|c|}{ Blood count } \\
\hline & & & & & & $\begin{array}{c}\text { Volume } \\
\text { in } 24 \mathrm{hrs} . \\
\mathrm{ml} .\end{array}$ & $\begin{array}{c}\mu \mathrm{g} \\
24 \mathrm{hrs} .\end{array}$ & p.p.m. & Hb. & $\mathbf{R}$ & W & $\mathbf{P}$ & $\mathbf{L}$ & $\mathbf{M}$ & E \\
\hline $\begin{array}{l}66 \\
67 \\
68 \\
69 \\
70 \\
71 \\
72\end{array}$ & $\begin{array}{l}23 \\
22 \\
30 \\
27 \\
22 \\
16 \\
18\end{array}$ & $\begin{array}{r}8 \\
7 \\
14 \\
3 \\
8 \\
2 \\
3\end{array}$ & $\begin{array}{l}\overline{-} \\
\overline{-} \\
\overline{-} \\
\overline{-} \\
-\end{array}$ & $\begin{array}{l}+ \\
+ \\
+ \\
+ \\
+\end{array}$ & $\begin{array}{l}\frac{ \pm}{+} \\
\pm \\
\frac{-}{+}\end{array}$ & $\begin{array}{l}\bar{Z} \\
\bar{Z} \\
\overline{\overline{1450}} \\
1310\end{array}$ & $\begin{array}{l}\bar{Z} \\
\bar{z} \\
\overline{1090} \\
264\end{array}$ & $\begin{array}{l}\bar{Z} \\
\bar{Z} \\
\overline{0} \\
0.751 \\
0.201\end{array}$ & $\begin{array}{r}112 \\
111 \\
99 \\
116 \\
90 \\
120 \\
127\end{array}$ & $\begin{array}{l}5 \cdot 5 \\
5 \cdot 4 \\
5 \cdot 1 \\
5.9 \\
4 \cdot 5 \\
6 \cdot 4 \\
5.9\end{array}$ & $\begin{array}{r}12.0 \\
9.3 \\
11.6 \\
8.2 \\
7.9 \\
6.4 \\
5.6\end{array}$ & $\begin{array}{l}62 \\
58 \\
46 \\
60 \\
59 \\
62 \\
65\end{array}$ & $\begin{array}{l}31 \\
37 \\
46 \\
35 \\
36 \\
33 \\
25\end{array}$ & $\begin{array}{l}7 \\
5 \\
7 \\
4 \\
5 \\
3 \\
5\end{array}$ & $\begin{array}{l}\overline{-} \\
1 \\
\frac{1}{-} \\
3\end{array}$ \\
\hline
\end{tabular}

acid was added slowly to clear the solution. To the cold solution $1 \mathrm{ml}$. of sodium arsenite solution was added, and a slow stream of hydrogen sulphide passed through for twenty minutes. The mixed sulphide precipitate was coagulated by bringing the mixture to the boil. The mixture was allowed to stand overnight, and the clear supernatant fluid decanted. The precipitate was transferred to a centri- fuge tube, spun out and washed twice with distilled water. Two $\mathrm{ml}$. of concentrated nitric acid and $1 \mathrm{ml}$. of concentrated hydrochloric acid were added, and the tube warmed in a water bath to dissolve the precipitate. The solution was transferred to a separating funnel, and the volume made up to about $100 \mathrm{ml}$; $5 \mathrm{gm}$. of hydroxylamine hydrochloride was added to remove the nitric acid which otherwise
דृ

产

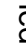


interfered with the dithizone blank. One ml. of concentrated hydrochloric acid was then added and the extraction of mercury and colour comparison carried out as in the case of the standard. A blank run was carried out each time a fresh lot of permanganate came into use. This blank was subtracted from each determination. The results were expressed as micrograms per 24 hours' excretion.

It was also desirable to study the daily variability in the excretion of mercury, and one volunteer from the blowing and finishing shop (Patient No. 35) undertook to collect his urine daily for a whole week. The figures obtained were as follows:

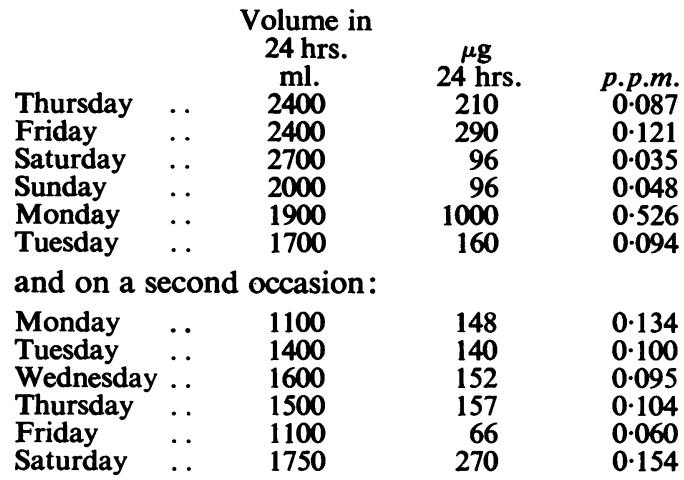

It was considered that this shows there is a considerable variability of the amount of mercury excreted in 24 hours, but that it is of the order which might be expected.

\begin{tabular}{|c|c|c|c|c|}
\hline & & $\begin{array}{r}\text { TAE } \\
\text { CON }\end{array}$ & & \\
\hline & & $\begin{array}{c}\text { Volume in } \\
24 \mathrm{hrs} . \\
\mathrm{ml} .\end{array}$ & $\underset{24 \mathrm{hr}}{\mu \mathrm{g}}$ & p.p.m. \\
\hline .. & . & 2250 & 23 & 0.010 \\
\hline .. & .. & 750 & 12 & 0.016 \\
\hline .. & .. & 2500 & 50 & 0.020 \\
\hline .. & .. & 2600 & 65 & 0.025 \\
\hline .. & .. & 1800 & 9 & 0.005 \\
\hline .. & . & 1950 & 48 & 0.025 \\
\hline .. & .. & 2000 & 40 & 0.020 \\
\hline .. & .. & 1000 & 5 & 0.005 \\
\hline .. & .. & 1000 & 10 & 0.010 \\
\hline .. & .. & 1800 & 90 & 0.050 \\
\hline . & . & 1000 & 20 & 0.020 \\
\hline .. & .. & 2000 & 10 & 0.005 \\
\hline & . & 750 & 30 & 0.040 \\
\hline$\ldots$ & .. & 1000 & 29 & 0.029 \\
\hline
\end{tabular}

An employee who had given long service to the firm became disgruntled, and decided to leave, for no clear reason. However, he was excreting a large amount of mercury in his urine, and it is highly possible that the act was a manifestation of erethism. Advantage was taken of the event to study the excretion of mercury after he had ceased to be exposed to it, and a 24-hour specimen was obtained 17 days after he left, when the excretion was found to be still present, though considerably lower.

\begin{tabular}{|c|c|c|c|}
\hline $\begin{array}{l}\text { Patient No. } 50 \\
\text { At work } \\
17 \text { days after }\end{array}$ & $\begin{array}{c}\text { Volume } \\
2460\end{array}$ & $\begin{array}{c}\mu \mathrm{g} / 24 \mathrm{hrs} . \\
2360\end{array}$ & $\begin{array}{r}\text { p.p.m. } \\
0.959\end{array}$ \\
\hline & 2132 & 1290 & 0.605 \\
\hline
\end{tabular}

\section{Environmental Observations}

The thermometer works was a long rectangular shop, 190 feet by 29 feet 6 inches, and of double width for the last 96 feet. It had a cubic capacity of 126,225 cubic feet. It was equipped with ventilators in the roof, and electric fans, and the number of air changes per hour was found to be slightly over two. At the near end the glass was cut into strips and blown, but no mercury was handled. In the middle the blowing and finishing were carried out, and the mercury added. At the far end the processes of boiling in and contracting, as well as calibrating, were performed. In a side room, threequarters of the way down the workshop, the mercury was stored, and heat treatment of the thermometer was carried out.

A number of estimations of the amount of mercury in the atmosphere of the shop were made, using the method of Milton (1946).

\section{Atmospheric Estimation}

Mercury Vapour. A sodium hypobromite solution was prepared by dissolving $5 \mathrm{ml}$. of bromine in $20 \mathrm{ml}$. of 10 per cent. sodium hydroxide solution; $15 \mathrm{ml}$. of this solution was placed in a bead-bubbler, and the atmosphere to be examined was sucked through the solution at 2 litres per minute until about 200 litres had been sampled. The exact volume of the sample was recorded. The contents of the bubbler were drained into a separating funnel and acidified with hydrochloric acid. The bromine liberated was removed by adding hydroxylamine hydrochloride, two to three grams, until the bromine colour disappeared; $1 \mathrm{ml}$. of concentrated hydrochloric acid was then added and the extraction of mercury and colour comparison carried out as in the case of the standards above.

Mercury Salts. To determine the amount of mercury present as particulate matter, a No. 42 Whatman filter paper in a cone-shaped bakelite holder was attached to the inlet tube of the bubbler. The paper was afterwards pulped in about $200 \mathrm{ml}$. of distilled water and oxidized as for urine (see below). The contents of the bubbler were treated as in the case of mercury vapour.

These estimations were carried out under different

TABLE 7

\begin{tabular}{|c|c|c|c|}
\hline Sampling point & Date & Temp. & $\begin{array}{l}\text { Concentra- } \\
\text { tion } \mathrm{Hg}\end{array}$ \\
\hline $\begin{array}{l}\text { Glass-blowing benches } \\
\text { (remote from } \mathrm{Hg} . \\
\text { working). }\end{array}$ & $\begin{array}{l}28.2 .45 \\
29.8 .45\end{array}$ & 二 & $\begin{array}{l}25 \mu \mathrm{g} / \mathrm{m}^{3} \\
25 \mu,\end{array}$ \\
\hline $\begin{array}{l}\text { Boiling in bench } \\
\text { (continuous } \mathrm{Hg} \\
\text { working). }\end{array}$ & $\begin{array}{l}28.2 .45 \\
10.3 .45 \\
22.3 .45 \\
29.8 .45\end{array}$ & $\begin{array}{c}17 \overline{5^{\circ}} \mathrm{C} . \\
20^{\circ} \mathrm{C} . \\
-\end{array}$ & $\begin{aligned} 100 & \\
10 & , \\
108 & , \\
42 & ,\end{aligned}$ \\
\hline $\begin{array}{c}\text { Treating room (Hg } \\
\text { centrifuged into } \\
\text { thermometer stems) }\end{array}$ & $\begin{array}{l}17.1 .45 \\
28.2 .42 \\
10.3 .45 \\
22.3 .45 \\
29.8 .45\end{array}$ & $\begin{array}{c}- \\
\overline{1} \\
29^{\circ} \mathrm{C} . \\
23^{\circ} \mathrm{C} . \\
-\end{array}$ & $\begin{aligned} 17 & , \\
175 & , " \\
70 & , " \\
670 & , "\end{aligned}$ \\
\hline
\end{tabular}


conditions of temperature, humidity, and wind direction, and show considerable variations. The concentration is increased in warm weather, and this is not surprising since air saturated with mercury vapour contains 1.84 p.p.m. at $20^{\circ} \mathrm{C}$. and 8.5 p.p.m. at $40^{\circ} \mathrm{C}$. These figures therefore indicate that the concentration of mercury is well below the saturation level, and that considerable variation in concentration could occur with local change in atmospheric conditions.

From these figures, however, it is clear that the workers are excreting far more mercury in their urine than they could possibly breathe in during a day. Assuming that a man breathes 10 cubic metres in a day, and he works in the mercury atmosphere for eight hours, the maximum mercury he could breathe in would be $356 \mu \mathrm{g}$. In the centrifuging room the atmosphere figures were higher, but even here it is extremely doubtful if the mercury excreted could be obtained from the air. In order to investigate the possibility of mercury being absorbed in other ways, bundles of finished thermometers were obtained and thoroughly washed in 20 per cent. ammonia. The washings were then estimated for mercury. Bundles of 50 thermometers taken at random were found to have on their surfaces the following quantities of mercury:

$675 \mu \mathrm{g}, 550 \mu \mathrm{g}, 100 \mu \mathrm{g}, 270 \mu \mathrm{g}, 550 \mu \mathrm{g}, 230 \mu \mathrm{g}$, $150 \mu \mathrm{g}, 40,000 \mu \mathrm{g}$, and $580 \mu \mathrm{g}$.

The workers on the heat treatment and 'boiling in 'processes were asked to wash their hands at the end of the day, and the washings were examined for mercury with the following results:

TABLE 8

\section{MERCURY IN $\mu$ g FROM WORKERS' HAND} WASHINGS

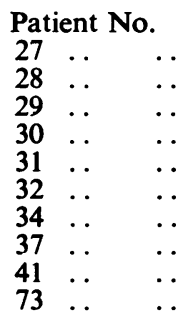

\begin{tabular}{|c|c|}
\hline $\begin{array}{c}\text { First vi } \\
9800 \\
3600 \\
7400\end{array}$ & $\begin{array}{r}\text { visit } \\
\mu \mathrm{g} \\
, " \\
,\end{array}$ \\
\hline $\begin{array}{r}3200 \\
200 \\
920 \\
800 \\
600 \\
2700\end{array}$ & \\
\hline
\end{tabular}

Second visit
$3200 \mu \mathrm{g}$
1680 ",
$6400 \quad "$
$7000 \quad "$
$7500 \quad "$
$2500 \quad "$
-
-

It is well known that mercury can be absorbed either through the respiratory tract, the alimentary tract or through the skin. All the evidence collected and put forward here, however, seems to establish that in thermometer workshops the absorption is principally through the skin, or alimentary track, and to a lesser degree through the respiratory tract.

Investigation at Chemical Factory

By contrast, the chemical factory was engaged in the manufacture of mercury salts. One section was devoted to the manufacture of mercuric and mercurous chlorides by the direct combination of mercury and chlorides under the influence of heat. The resultant salt was crushed and packed, and a fine particulate dust of mercuric chloride pervaded the atmosphere.
A second section of the factory was devoted to the manufacture of mercury oxides and iodides. This process consisted of treating the chlorides with alkalis or potassium iodide in the wet condition. The resultant precipitate was filtered and dried in ovens. Subsequent crushing and sieving of the dried salts was a dusty process and quite high concentrations of mercury were found in the atmosphere. Beside the main room there was a small weighing booth in which stood large, open dishes of mercury metal. The workers in this factory used sweat rags to keep the dust from the respiratory tract, but examination of the nostrils showed that much dust penetrated this protection.

TABle 9

\begin{tabular}{|c|c|c|}
\hline Sampling point & Date & $\begin{array}{c}\text { Concentration } \\
\text { of } \mathbf{~ H g}\end{array}$ \\
\hline $\begin{array}{l}\text { Weighing } \\
\text { vapour). }\end{array}$ booth $\quad(\mathrm{Hg}$ & $\begin{array}{l}21.11 .44 \\
28.11 .44\end{array}$ & $\begin{array}{l}185 \mu \mathrm{g} / \mathrm{m}^{3} \\
290 \mu, "\end{array}$ \\
\hline $\begin{array}{l}\text { Process room (Hg oxides } \\
\text { and iodides manufac- } \\
\text { tured). }\end{array}$ & $\begin{array}{l}21.11 .44 \\
28.11 .44\end{array}$ & $\begin{array}{l}400 ", \\
280 "\end{array}$ \\
\hline $\begin{array}{l}\text { Sieving room (Hg oxides } \\
\text { dried, washed and sieved) }\end{array}$ & $\begin{array}{l}21.11 .44 \\
28.11 .44\end{array}$ & $\begin{array}{r}1300 ", \\
18,000 "\end{array}$ \\
\hline $\begin{array}{l}\text { Sublimate room (manufac- } \\
\text { ture). }\end{array}$ & 20.12 .44 & 380 \\
\hline $\begin{array}{l}\text { Sublimate room (crushing } \\
\text { and packing). }\end{array}$ & 20.12 .44 & 670 \\
\hline
\end{tabular}

However, the amount excreted in the urine of the workers was, on the whole, less. The symptoms were also less well marked. Whether this indicates a different reaction to mercury metal as compared with the salts of mercury, or whether it is simply related to the amount absorbed, it is not possible to say.

It must be remembered also that calomel is made as a pharmaceutical preparation to be taken by mouth, and that a large number of the population take a considerable amount in this way, and yet never suffer from chronic mercurialism.

\section{Prevention}

The evidence of Neal and his colleagues (1941) that mercury poisoning does not occur if the concentration of mercury in the atmosphcre is less than $100 \mu \mathrm{g}$ per cu. m., logether with the fact that men in the thermometer shop were excreting more mercury than could be absorbed from the air, indicates that, in these shops, measures should be directed towards cleanliness. Adequate washing facilities must be provided, and there must be strict supervision to ensure that the workers cleanse their hands and skin fully after each shift and before all meals. Mercury can seep into crevices, penetrate wooden floors, collect in interstices, mix with dust or amalgamate with solid metals. It vaporizes at room temperature and, therefore, potentially 
TABLE 10

WORKERS IN CHEMICAL FACTORY

\begin{tabular}{|c|c|c|c|c|c|c|c|c|c|c|c|c|c|c|c|}
\hline \multirow{2}{*}{$\begin{array}{l}\text { Case } \\
\text { No. }\end{array}$} & \multirow[b]{2}{*}{ Age } & \multirow{2}{*}{$\begin{array}{c}\text { Duration } \\
\text { of employ- } \\
\text { ment. } \\
\text { Years }\end{array}$} & \multirow[b]{2}{*}{ Erethism: } & \multirow[b]{2}{*}{ Tremor } & \multirow[b]{2}{*}{$\underset{\text { titis }}{\text { Stoma- }}$} & \multicolumn{3}{|c|}{ Urine } & \multicolumn{7}{|c|}{ Blood count } \\
\hline & & & & & & $\begin{array}{c}\text { Volume } \\
\text { :n } 24 \text { hrs. } \\
\text { ml. }\end{array}$ & $\begin{array}{c}\mu \mathrm{g} \\
24 \mathrm{hrs}\end{array}$ & p.p.m. & Hb. & $\mathbf{R}$ & $\mathbf{W}$ & $\mathbf{P}$ & L & $\mathbf{M}$ & E \\
\hline $\begin{array}{l}73 \\
74 \\
75 \\
76 \\
77 \\
78 \\
79 \\
80 \\
81 \\
82 \\
83\end{array}$ & $\begin{array}{l}53 \\
52 \\
62 \\
36 \\
46 \\
54 \\
38 \\
25 \\
54 \\
46 \\
51\end{array}$ & $\begin{array}{r}25 \\
33 \\
31 \\
5 \\
21 \\
5 \\
5 \\
5 \\
\frac{1}{2} \\
3 \\
40\end{array}$ & $\begin{array}{l}+ \\
- \\
- \\
- \\
- \\
- \\
- \\
- \\
- \\
-\end{array}$ & $\begin{array}{l}+ \\
- \\
- \\
- \\
+ \\
- \\
- \\
+ \\
- \\
+\end{array}$ & $\begin{array}{l}- \\
- \\
- \\
- \\
- \\
+ \\
- \\
+ \\
- \\
+\end{array}$ & $\begin{array}{c}1000 \\
1900 \\
1900 \\
2400 \\
1400 \\
\overline{1700} \\
2400 \\
2200 \\
-\end{array}$ & $\begin{array}{r}520 \\
750 \\
520 \\
1.360 \\
530 \\
\overline{450} \\
590 \\
\overline{640} \\
-\end{array}$ & $\begin{array}{c}0.520 \\
0.395 \\
0.273 \\
0.566 \\
0.378 \\
-\overline{0} \\
0.264 \\
0.249 \\
0.291 \\
-\end{array}$ & $\begin{array}{l}100 \\
104 \\
112 \\
106 \\
108 \\
100 \\
114 \\
114 \\
\frac{100}{100} \\
100\end{array}$ & $\begin{array}{l}5.7 \\
5.2 \\
5.5 \\
5.3 \\
5.4 \\
5.1 \\
5.7 \\
5.7 \\
5.3 \\
5.0\end{array}$ & $\begin{array}{r}6.2 \\
9.9 \\
10.5 \\
7.9 \\
10.0 \\
6.3 \\
8.1 \\
8.5 \\
7.7 \\
5.5\end{array}$ & $\begin{array}{l}67 \\
67 \\
66 \\
73 \\
63 \\
72 \\
76 \\
66 \\
61 \\
56\end{array}$ & $\begin{array}{l}31 \\
33 \\
30 \\
24 \\
33 \\
23 \\
21 \\
33 \\
37 \\
42\end{array}$ & $\begin{array}{l}\overline{-} \\
\frac{1}{E} \\
-1 \\
\overline{-} \\
\overline{-}\end{array}$ & $\begin{array}{l}1 \\
- \\
3 \\
3 \\
1 \\
3 \\
1 \\
1 \\
2\end{array}$ \\
\hline
\end{tabular}

hazardous concentrations may occur in the atmosphere from seemingly negligible spillage. Wooden construction should be avoided; floors of concrete or composition material should be maintained without cracks or open interstices. Benches should be tilted so that mercury can be drained and collected, thus preventing vaporization and contact with the skin; wherever possible mercury should be used in closed procedures. Ventilation is a difficult problem and the mistake of forcibly ventilating open rooms must be avoided, since it increases the vaporization of mercury. Exhausts should be placed to draw off the air from apparatus where mercury is used, and the work space should be supplied with fresh air from an outside source. Concentrations of mercury in the atmosphere should never rise above $75 \mu \mathrm{g}$ per cu. $\mathrm{m}$. whatever the weather conditions, and mercury vapour detector apparatus is now available (Woodson 1939).

\section{Summary}

The symptoms of chronic mercury poisoning are erethism, tremor and stomatitis. Seventy-two men in a thermometer workshop and 11 in a chemical works making pharmaceutical compounds of mercury were examined. Mass observation suggests that the thermometer workers suffered from mild chronic mercury poisoning, whereas little abnormality was seen in the older group of chemical workers. Atmosphere and urine estimations showed that the thermometer makers were excreting up to 10 times as much mercury in a day as could possibly be absorbed from the atmosphere. Washings from bundles of finished thermometers and from the workers' hands at the end of the day suggest that this is to be explained by absorption of metallic mercury through the skin, or ingestion through the alimentary tract.

\section{Acknowledgements}

We wish to thank Dr. A. D. Belilios and Dr. H. Wyers for the great help they have given us during this investigation; and Messrs. Zeal \& Co., and Messrs. May and Baker, Ltd., without whose co-operation the work could not have been undertaken; and Mr. W. D. Duffield and Mr. L. Hoskins for technical help.

\section{REFERENCES}

Adler, L. H. (1891). Medical News, 59, 186.

Almkvist (1929). Acta. med. scand., 70, 464. Bioomfield, J. J., Trasko, V. N., Sayers, R. R., Page, R. T.,
Peyton, M.F. (1940). U.S. Publ. Health Bull. No. 259, 199. Christensen, H., Krogh, M., and Nielsen, M. (1937). Nature, 139, 626.

Dennis, L. (1876). Rep. Board Health, New Jersev, 2, 67.

Dunajewsky, M. I., and Peissakhovitch, I. M. (1930). Arch. Gewerbepath. u. hyg. 1, 511

Evans, H., and Perry, K. M. A. (1943). Lancet, 1, 576.

Freeman, J. A. (1860). Trans. Med. Soc. New Jersey, 61.

Hamilton, A. (1922). J. industr. Hyg., 4, 219.

- (1943). Exploring the Dangerous Trades, Boston.

Hunter, D., Bomford, R. R., Russell, D. (1940). Quart. J. med., 9,

Jacobsohn, W. (1920). J. industr. hyg., 2, 193.

Lewis, L. (1945). J. Amer. med. assoc., 129, 123.

McCarroll, C. F. (1939). U.S. Bureau of Mines Rept., 3475.

McGeorge, J. R. (1935). J. Amer. dent. assocn., 22, 60.

Macleod, J. M. H. (1916). Brit. J. Derm. Syph., 28, 135.

Matussevic, J. S., and Frumina, D. M. (1936). Rassegna di medicina applicata al Lavaro Industriala, 7, 1.

Milton, R. (1946). To be published.

Neal, P. A., Fliner, R. H., Edwards, T. I., Reinhart, W. H., Hough, J. W., Dallavalle, J. M., Goldram, F. H., Armstrong, D. W., Gray, A. S., Coleman, A. L., Posyman, B. F. (1941). U.S. Prayl. Health Bull. No. 263 .

Rosen, G. (1943). The History of Miners' Diseases, Schuman, New York.

Stock, A. (1931). Z. f. angew. Chem., 44, 200.

(1943). Bir. Deutsch chem. gesellschaft., 75, 1530

Storlazzi, E. D., Elkins, H. B. (1941). J. industr. hyg., 23, 459.

Taylor, A. G. (1864). Guy's Hospital Reports, 10, 173.

Taylor, J. G. (1901). Ibid., 40, 171.

Tylecote, F. E. (1912). Lancet, 1, 1137.

Woodson, T. T. (1939). Rev. Scient. Instruments, 10, 308. 